Котик О. В., асистент, Бояр О. Л., магістр (Національний університет водного господарства та природокористування, м. Рівне)

\title{
СУТНІСТЬ, ОСОБЛИВОСТІ ФОРМУВАННЯ ТА ВИКОРИСТАННЯ ФІНАНСОВИХ РЕСУРСІВ ПІДПРИЕМСТВА
}

У статті розкрито сутність фінансових ресурсів підприємства та наведено їх класифікацію. Досліджено теоретичні основи формування фінансових ресурсів та виділено напрямки їх використання, а також здійснено аналіз структури фінансових ресурсів на підприємствах України.

Ключові слова: підприємство, фінансові ресурси, власний капітал, позиковий капітал.

Постановка проблеми. Нинішнє становлення та розвиток ринкової економіки України зумовлюють необхідність дослідження процесів фінансування суб'єктів господарювання, в тому числі формування та використання фінансових ресурсів, наявність яких $€$ гарантією стабільності та економічного розширення діяльності підприємств. 3 початком перебудови економіки більшість підприємств та організацій змінили форму власності та організаційно-правову форму господарювання, в наслідок чого третина з них стала збитковими, а в інших спостерігається дефіцит фінансових ресурсів, низький рівень здатності до самофінансування, нераціональний розподіл капіталу між сферами виробництва та обігу, скорочення обсягів виробництва та порушення динамічної рівноваги із зовнішнім середовищем. Фінансові ресурси за цих умов мають першочергове значення, оскільки вони супроводжують всі етапи функціонування суб'єкта господарювання і відносяться до єдиного виду ресурсного потенціалу підприємства, який з мінімальним проміжком часу трансформується в будь-який інший вид ресурсів. Тому важливим залишається розуміння сутності та складу фінансових ресурсів, а також застосування ефективних інструментів в процесі їх формування та використання. Виходячи з цього можна стверджувати, що актуальність обраної теми визначена особливо важливою роллю фінансових ресурсів у виробничо-господарській діяльності підприємства, а також складністю управління процесами формування та подальшому використанні фінансових ресурсів з врахуванням погіршення ситуації неконтрольованих зовнішніх факторів, які значним чином впливають на життєді- 
яльність підприємства.

Аналіз останніх публікацій. Поняття фінансових ресурсів $\epsilon$ предметом дослідження багатьох науковців вже багато років і їх роль в сучасних умовах ведення господарської діяльності важко переоцінити. Питанням, що пов'язані з дослідженням суті та принципів ефективного формування та використання фінансових ресурсів підприємств, присвячували праці чимало зарубіжних та вітчизняних провідних науковців. Вагомий внесок у розвиток теорії та практики організації управління фінансовими ресурсами підприємств зробили такі науковці, як І. Бланк, О. Близнюк, А. Завгородній, Г. Кірейцев, Л. Лахтіонова, В. Опарін, О. Філімоненков тощо. Проте єдиного трактування фінансових ресурсів підприємства як економічної категорії на сьогодні відсутнє, оскільки окремі науковці ототожнюють фінансові ресурси 3 грошовими коштами, грошовими потоками чи капіталом підприємства, інші - цілком розмежовують ці поняття, а деякі вчені визначають один термін через інший.

Постановка завдання. Мета статті полягає в уточненні поняття «фінансові ресурси», розгляді основних складових цієї економічної категорії і їх визначної ролі в загальному процесі формування та використання фінансових ресурсів, а також виявлення проблем формування фінансових ресурсів на підприємствах України та пошук напрямів їх вирішення.

Виклад основного матеріалу дослідження. На сьогодні існує безліч різноманітних підходів до визначення економічної сутності фінансових ресурсів підприємства, що підтверджується узагальненими даними у табл. 1.

Таблиця 1

Дослідження сутності поняття «фінансові ресурси»

\begin{tabular}{|c|c|}
\hline Автор & Визначення поняття «фінансові ресурси», джерело \\
\hline 1 & 2 \\
\hline І. А. Бланк & $\begin{array}{l}\text { Сукупність акумульованих власних і позикових ко- } \\
\text { штів та їх еквівалентів у формі цільових грошових } \\
\text { фондів, призначених для забезпечення його госпо- } \\
\text { дарської діяльності в майбутньому періоді [1] }\end{array}$ \\
\hline $\begin{array}{c}\text { А. Г. Завгоро- } \\
\text { дній }\end{array}$ & $\begin{array}{l}\text { Грошові кошти, які є в розпорядженні підприємства } \\
\text { і призначені для здійснення поточних витрат і ви- } \\
\text { трат із розширеного відтворення, для виконання } \\
\text { фінансових зобов'язань і економічного стимулю- } \\
\text { вання працівників [3] }\end{array}$ \\
\hline
\end{tabular}


продовження табл. 1

\begin{tabular}{|c|c|}
\hline 1 & 2 \\
\hline Г.Г.Кірейцев & $\begin{array}{l}\text { Грошові доходи і надходження підприємства, } \\
\text { що призначенні для виконання його фінансових } \\
\text { зобов'язань і фінансування витрат щодо забез- } \\
\text { печення розширеного відтворення [4] }\end{array}$ \\
\hline Л. А. Лахтіонова & $\begin{array}{l}\text { Грошові кошти у формі грошових фондів (стату- } \\
\text { тний фонд, фонд оплати праці, резервний } \\
\text { фонд) та у нефондовій формі (використання } \\
\text { грошових коштів для виконання фінансових } \\
\text { зобов'язань перед бюджетом і позабюджетними } \\
\text { фондами, банками, страховими кампаніями та } \\
\text { ін.) [5] }\end{array}$ \\
\hline В. М. Опарін & $\begin{array}{l}\text { Сукупність грошових фондів цільового призна- } \\
\text { чення, сформованих у процесі розподілу і пере- } \\
\text { розподілу валового внутрішнього продукту, } \\
\text { створеного на підприємстві, якими воно розпо- } \\
\text { ряджається на правах власності або повного го- } \\
\text { сподарського відання і використовує на статутні } \\
\text { потреби [6] }\end{array}$ \\
\hline О.С. Філімоненков & $\begin{array}{l}\text { Сукупність власного, позикового і залученого } \\
\text { грошового капіталу, який використовується } \\
\text { підприємствами для формування своїх активів } \\
\text { здійснення виробничо-фінансової діяльності } \\
\text { метою одержання відповідного доходу [8] }\end{array}$ \\
\hline
\end{tabular}

Аналізуючи вищенаведені визначення поняття «фінансові ресурси підприємства», можемо зазначити, що серед українських та зарубіжних науковців відсутня єдина думка щодо трактування цього терміну та його ролі у процесі функціонування будь-якого підприємства, оскільки його розглядають вчені різних галузей економіки (статистика, фінансовий менеджмент, маркетинг, фінанси, політична економія), вкладаючи у трактування відповідне для галузі значення. Але обґрунтовані наукові підходи до різних точок зору дають змогу сформулювати власне визначення, що фінансові ресурси підприємства - це грошові кошти у вигляді власного та залученого капіталу, якими розпоряджається підприємство на правах власності для формування своїх активів, виконання певних фінансових зобов'язань та здійснення безперебійної виробничо-господарської діяльності.

На основі цього визначення сформуємо класифікацію фінансових ресурсів, що, на нашу думку, відображатиме їх найважливіші 
якості (рисунок). 3 даної класифікації видно, що за походженням фінансові ресурси поділяються на власні, залучені і позичені.

Власні фінансові ресурси за джерелами формування в свою чергу поділяються на зовнішні (залучення підприємством додаткового пайового або акціонерного капіталу, безоплатна фінансова допомога, безкоштовно передані підприємству матеріальні і нематеріальні активи, що включаються до складу його балансу) та внутрішні (статутний капітал, виручка від реалізації, чистий прибуток підприємства, резерви, накопичені підприємством, амортизаційні відрахування).

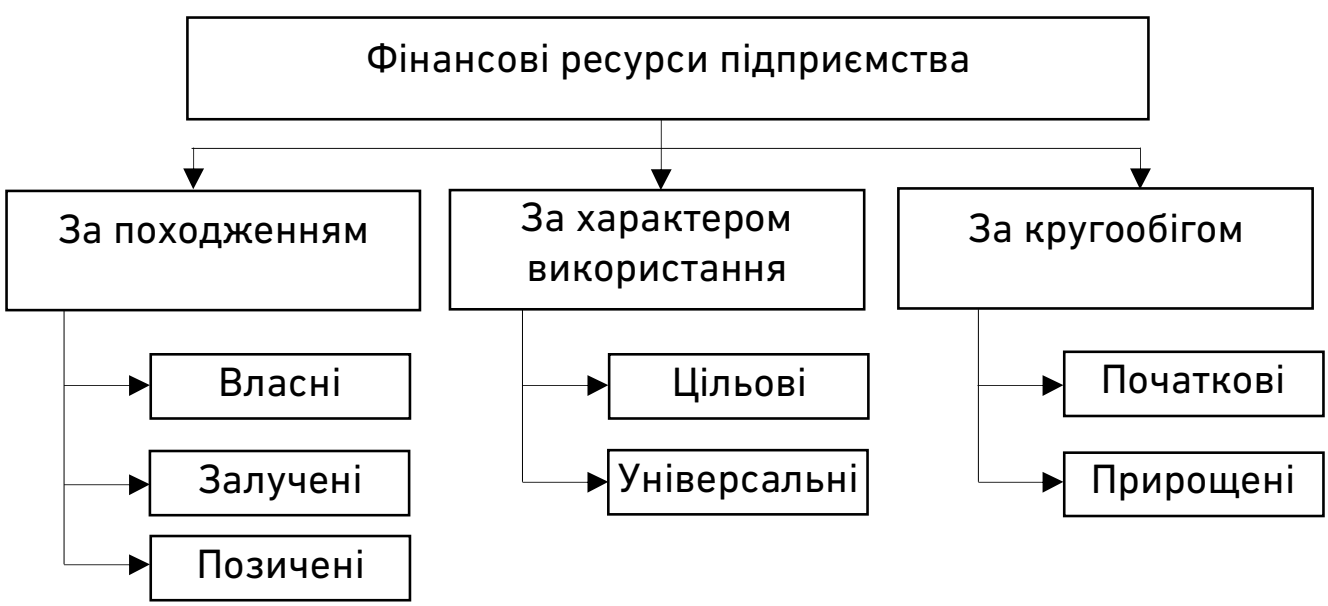

Рисунок. Класифікація фінансових ресурсів підприємства Джерело: розроблено автором за даними [4]

Залучені кошти включають в себе заборгованість за авансами замовників, заборгованість по оплаті праці, заборгованість за внесками до бюджетів різних рівнів та вільні кошти резервів. Позичені кошти - це ті, що одержує підприємство на визначений термін, за плату й на умовах повернення. Формуються вони, переважно, за рахунок коротко- і довгострокових кредитів банків.

За характером використання розрізняють цільові та універсальні фінансові ресурси. Цільові фінансові ресурси - це ресурси, що мають цільове призначення і використовуються на вказані цілі (кошти амортизаційного, резервного фонду, бюджетних асигнувань тощо). Універсальні фінансові ресурси використовуються на різні цілі: фінансові вкладення, благодійні внески тощо. Фінансові ресурси також класифікують за кругообігом на початкові - ті, з якими розпочинає підприємство свою діяльність, і прирощені - ті, що створюються в процесі діяльності [4].

Найважливішим джерелом формування майна будь-якого підприємства виступає статутний капітал через те, що здійснення вироб- 
ничо-господарської діяльності вимагає відповідної фінансової підтримки. Статутний капітал ще називають початковим, оскільки це величина, що відображає вартісну оцінку внесків, які першочергово були інвестовані власниками (учасниками) даного підприємства. У певній мірі розмір статутного капіталу впливає на можливості зовнішнього фінансування, ділову репутацію підприємства.

Для того, щоб на новоствореному підприємстві забезпечувалось ведення нормальної виробничо-господарської діяльності, величина статутного капіталу спрямовується: на придбання основних фондів та формування необхідної кількості оборотних ресурсів, на купівлю промислових зразків, товарних знаків, авторських прав, ноу-хау та виключних прав на використання зазначених предметів з можливістю отримання майбутньої економічної вигоди від реалізації або використання активу.

Таким чином, в процесі інвестування початкового капіталу у виробництво, утворюється вартість, яка виражена ціною реалізованої продукції. Після продажу виготовленої продукції вартість приймає грошову форму у вигляді виручки від реалізації, яка надходить на розрахунковий рахунок. Отримана виручка ще не вважається прибутком, однак вона є джерелом відшкодування матеріальних затрат та формування фінансових резервів, які $€$ особливою групою фондів грошових коштів, що тимчасово вилучаються з обороту з метою подальшого фінансування непередбачуваних збоїв на підприємстві. Також у складі виручки від реалізації виокремлюють суму амортизаційних відрахувань, складову фінансових ресурсів, що утворюють цільовий фонд, призначений для відтворення, оновлення зношених у процесі виробництва необоротних матеріальних активів. При дотриманні оптимального співвідношення між різними джерелами формування фінансових ресурсів підприємство зможе утримувати фінансову рівновагу, а також оперативно реагувати на зміну ринкового попиту та розширювати масштаби виробництва.

Використання фінансових ресурсів може здійснюватися підприємством за такими напрямками:

- платежі організаціям фінансово-банківської системи, обумовлені виконанням фінансових зобов'язань (податкові платежі до бюджету, страхові платежі, виплата відсотків за користування банківськими кредитами, погашення раніше отриманих позик тощо);

- інвестування власних коштів в капітальні затрати (реінвестування), пов'язане з розширенням та технічним оновленням виробництва, переходом на нові прогресивні технології, використання «ноухау» тощо); 
- інвестування фінансових ресурсів у цінні папери інших суб'єктів господарювання: акції, облігації, які $€$ об'єктом купівліпродажу на ринку;

- використання фінансових ресурсів на забезпечення потреб соціального характеру, на благодійні цілі, спонсорство тощо [5].

3 практичної точки зору, напрями використання фінансових ресурсів підприємства варто згрупувати за видами активів та витрат, що дозволить врахувати специфіку кожного елементу:

1. За видами активів:

- необоротні активи (основні засоби, нематеріальні активи, незавершене будівництво, довгострокові фінансові вкладення, інші активи);

- оборотні активи (запаси, дебіторська заборгованість, короткострокові фінансові вкладення).

2. За видами витрат:

- на виробництво продукції (матеріальні витрати, оплата праці, відрахування на соціальні заходи, інші витрати);

- на збут продукції (транспортні затрати, реклама, представницькі витрати, зберігання і реалізація продукції, страхування, нормативні недостачі);

- управлінські витрати (адміністративно-управлінські витрати, утримання загальногосподарського персоналу, витрати на інформаційні, аудиторські, консалтингові послуги);

- інші витрати (відсотки до оплати, витрати по наданню в тимчасове користування активів підприємства, витрати по вибуттю основних засобів та інших активів, оплата послуг кредитних організацій) [8].

Варто відмітити, що на формування й використання фінансових ресурсів підприємств впливають різноманітні чинники, які поділяються на внутрішні - пов'язані безпосередньо з діяльністю окремого підприємства, та зовнішні - що не пов'язані з діяльністю підприємства, але впливають на неї. До внутрішніх чинників ми можемо віднести:

- рівень досконалості фінансової структури підприємства;

- забезпечення зв'язку збутової стратегії з виробничою;

- якість організації управління фінансовими ресурсами;

- вибір сегментів ринку згідно з виробничими можливостями;

- якість фінансового, управлінського та податкового обліку;

- здійснення цінової політики, виходячи із затрат на виробництво, пошук шляхів їх зниження;

- налагодження роботи з посередницькими організаціями;

- загальна оцінка ефективності функціонування виробництва та 
узгодження іï із фінансовим планом підприємства [2, С. 1-7].

Що стосується зовнішніх чинників, то до них відносять інфляцію, що значно впливає на величину грошових потоків, структурні зміни капіталу, які викликані змінними банківськими відсотками та курсами валют; зростання цін на ресурси, зміну політичного курсу влади, законодавчі нововведення (зокрема в податковому законодавстві), зниження централізованого фінансування, стан економіки в цілому.

Внутрішні чинники підприємство може самостійно контролювати завдяки систематичному проведенні економічного аналізу, а ось на зовнішні - підприємство впливу не має і це призводить до збоїв у господарській діяльності, адже при нестабільній економіці підприємства зазнають значних збитків.

Проведемо аналіз джерел формування фінансових ресурсів і напрямів їх вкладення на прикладі підприємств України за 20132017 роки (табл. 2).

Таблиця 2

Загальна структура фінансових ресурсів підприємств України за 2013-2017 роки, \%

\begin{tabular}{|c|c|c|c|c|c|}
\hline Показники & $\begin{array}{c}2013 \\
\text { рік }\end{array}$ & $\begin{array}{c}2014 \\
\text { рік }\end{array}$ & $\begin{array}{l}2015 \\
\text { рік }\end{array}$ & $\begin{array}{c}2016 \\
\text { рік }\end{array}$ & $\begin{array}{c}2017 \\
\text { рік }\end{array}$ \\
\hline \multicolumn{6}{|c|}{ Джерела формування фінансових ресурсів } \\
\hline Власний капітал & 34 & 25 & 28 & 24 & 25 \\
\hline $\begin{array}{l}\text { Довгострокові зо- } \\
\text { бов'язання }\end{array}$ & 19 & 23 & 21 & 17 & 17 \\
\hline Поточні зобов'язання & 47 & 53 & 51 & 59 & 58 \\
\hline Разом & 100 & 100 & 100 & 100 & 100 \\
\hline \multicolumn{6}{|c|}{ Напрямки використання фінансових ресурсів } \\
\hline Необоротні активи & 46 & 45 & 50 & 42 & 43 \\
\hline Оборотні активи & 54 & 55 & 50 & 58 & 57 \\
\hline Разом & 100 & 100 & 100 & 100 & 100 \\
\hline
\end{tabular}

Джерело: розроблено автором за даними [7]

Дані вищенаведеного дослідження свідчать про те, що:

- за аналізований період для підприємств характерне зростання поточних зобов'язань у джерелах формування фінансових ресурсів;

- відбувається непропорційне зменшення частки власного капіталу у вітчизняних суб'єктів господарювання і зростання їх залежності від зовнішніх джерел фінансування, що $є$ негативним явищем; 
- зростає питома вага довгострокових зобов'язань у загальній структурі фінансових ресурсів.

Відповідно до напрямів вкладення фінансових ресурсів найбільшу питому вагу в складі активів підприємств займають оборотні активи.

Фінансування більшою мірою за рахунок залучених коштів свідчить про неспроможність підприємств своєчасно розрахуватися за своїми зобов'язаннями, забезпечити ефективний розвиток за рахунок власних джерел, а також про підвищення залежності від кредиторів. Це, в свою чергу, негативно впливає на ліквідність та платоспроможність і на рівень фінансової стійкості підприємств України. При низькому рівні фінансової стійкості підприємства не здатні забезпечувати безперервний процес виробничо-торгівельної діяльності, а також покрити затрати на своє розширення і оновлення. Вважаємо, що однією з внутрішніх причин кризового стану багатьох вітчизняних підприємств $€$ неефективне виконання фінансовими службами покладених на них зобов'язань, зокрема недостатнє інформаційне забезпечення за підсумками роботи підприємства, тобто надання неповної, неправдивої інформації, на основі якої приймаються невиправдані управлінські рішення.

Отже, для раціонального формування та використання фінансових ресурсів доцільно дотримуватися необхідного рівня платоспроможності та ліквідності для покриття поточних зобов'язань, економного використання фінансових ресурсів, проведення грамотної дивідендної політики, ведення контролю над виробництвом та збутом для підвищення рівня рентабельності, проведення заходів щодо модернізації виробництва, дотримання оптимальної структури власних та позикових коштів для підтримки платоспроможності у довгостроковому періоді залежно від сфери діяльності підприємства.

Висновки. Основою функціонування підприємств різних галузей $€$ фінансові ресурси. При їх правильному формуванні та використанні в умовах нестабільної економічної ситуації в Україні, фінансові ресурси повинні забезпечувати безперервне виробництво і функціонування підприємств. А для цього підприємству необхідно враховувати велику кількість як внутрішніх, так і зовнішніх факторів під час їх формування. Ці фактори вимагатимуть врахування певних особливостей при формуванні величини та структури фінансових ресурсів. Також підприємства мають визначити правильне поєднання власних і позикових джерел фінансування, яке забезпечить їм стабільне функціонування і можливість отримання прибутків. Проте, в період нестабільної економічної ситуації підприємствам доцільно буде залучати кошти для підтримки свого функціонування та розвитку підприєм- 
ства. Це можна здійснювати за рахунок залучених фінансових ресурсів, зокрема кредиторської заборгованості, у силу неможливості повною мірою використати власні джерела фінансування через збитковість своєї діяльності.

1. Бланк І. А., Горпинченко А. П. Фінансовий менеджмент. К. : Ельга, НікаЦентр, 2007. 521 с. 2. Близнюк О. П. Класифікація джерел формування фінансових ресурсів підприємства. Вісник Міжнародного Слов'янського університету. 2015. № 2. С. 1-7. 3. Завгородній А. Г., Вознюк Г. Л., Смовженко Т. С. Фінансовий словник. 3-тє вид., перероб. і доп. К. : Знання, 2000. 404 с. 4. Кірейцев Г. Г. Фінансовий менеджмент. К. : ЦУЛ, 2007. 496 с. 5. Лахтіонова, Л. А. Фінансовий аналіз суб'єктів господарювання : монографія. К. : КНЕУ, 2001. 387 с. 6. Опарін В. М. Фінансові ресурси та суспільний капітал. Вісник НБУ. 2001. № 7. С. 26-28. 7. Офіційний сайт Державної служби статистики України. URL: www.ukrstat.gov.ua. (дата звернення: 15.11.2018). 8. Філімоненков О. С. Фінанси підприємств : навч. посіб. 2-ге вид., перероб. і доп. К. : МАУП, 2004. 328 с.

\section{REFERENCES:}

1. Blank I. A., Horpynchenko A. P. Finansovyi menedzhment. K. : Elha, NikaTsentr, 2007. 521 s. 2. Blyzniuk 0. P. Klasyfikatsiia dzherel formuvannia finansovykh resursiv pidpryiemstva. Visnyk Mizhnarodnoho Slovianskoho universytetu. 2015. № 2. S. 1-7. 3. Zavhorodnii A. H., Vozniuk H. L., Smovzhenko T. S. Finansovyi slovnyk. 3-tie vyd., pererob. i dop. K. : Znannia, 2000. 404 s. 4. Kireitsev H. H. Finansovyi menedzhment. K. : TsUL, 2007. 496 s. 5. Lakhtionova, L. A. Finansovyi analiz subiektiv hospodariuvannia : monohrafiia. K. : KNEU, 2001. 387 s. 6. Oparin V. M. Finansovi resursy ta suspilnyi kapital. Visnyk NBU. 2001. № 7. S. 26-28. 7. Ofitsiinyi sait Derzhavnoi sluzhby statystyky Ukrainy. URL: www.ukrstat.gov.ua. (data zvernennia: 15.11.2018). 8. Filimonenkov 0. S. Finansy pidpryiemstv : navch. posib. 2-he vyd., pererob. i dop. K. : MAUP, 2004. 328 s.

Рецензент: к.е.н., доцент Кондрацька Н. М. (НУВГП)

Kotyk O. V., Assistant, Boiar O. L., Master (National University of Water and Environmental Engineering, Rivne)

\section{ESSENCE, FEATURES OF FORMATION AND USE OF THE ENTERPRISE'S FINANCIAL RESOURCES}

Financial resources accompany all stages of the enterprise and relate to one type of resource potential, which with a minimum period of time is transformed into any other type of resources. Therefore, it remains 
important to understand the nature and composition of financial resources, as well as the use of effective tools in the process of their formation and use. The article reveals the essence of the financial resources of the enterprise and provides diverse definitions of this concept by various researchers. It has been determined that the presence of financial resources of an enterprise is a guarantee of stability and economic expansion of its activities. With the classification of financial resources under consideration, which reflects their most important properties, it has been investigated that, by origin, financial resources are divided into own, attracted and borrowed. The authors disclose the theoretical foundations of the formation of financial resources and highlight the main directions of their use, including by types of assets and expenses. It was determined that the most important source of formation of the property of any enterprise is the authorized capital due to the fact that the implementation of production and business activities requires appropriate financial support. The article also identifies internal and external factors affecting financial resources. It is known that an enterprise can independently control internal factors due to the systematic carrying out of economic analysis, but the enterprise has no influence on external factors and this leads to disruptions in economic activity, because in an unstable economy, enterprises incur significant losses. Due to the structural analysis of the sources of financial resources and the directions of their investments over the past five years, the enterprises of Ukraine considered problems and suggested the best ways to solve them.

Keywords: enterprise, financial resources, equity, loan capital.

Котик О. В., ассистент, Бояр О. Л., магистр (Национальный университет водного хозяйства и природопользования, г. Ровно)

СУЩНОСТЬ, ОСОБЕННОСТИ ФОРМИРОВАНИЯ И ИСПОЛЬЗОВАНИЯ ФИНАНСОВЫХ РЕСУРСОВ ПРЕДПРИЯТИЯ

В статье раскрыта сущность финансовых ресурсов предприятия и приведена их классификация. Исследованы теоретические основы формирования финансовых ресурсов и выделены направления их использования, а также проведен анализ структуры финансовых ресурсов на предприятиях Украины.

Ключевые слова: предприятие, финансовые ресурсы, собственный капитал, заемный капитал. 